\title{
Some factors affect the perception and production of pheromone and ultrastructure of antennae after treatment of Tribolium castaneum with Chlorfluazuron
}

Olfat M. El-Monairy ${ }^{1}$; Nehad M, El-barky ${ }^{1}$; Reda F. A. Bakr ${ }^{2 \& 3}$; and Nancy M. B. El-shourbagy ${ }^{1}$.

1- Entomology Department, Faculty of Science, Benha University, Qalyubiya, Egypt.

2- Entomology Department - Faculty of Science- Ain Shams University 3-Biology Department, Faculty of Science, King Khalid University, Abha, Saudi Arabia

\section{ABSTRACT}

Chlorfluazuron (Atabron) is an insect growth regulator (IGR) used for controlling the major stored product pests. This study investigate the effect of Chlorfluazuron on both sexes of Tribolium castaneum which resulted from treated $4^{\text {th }}$ larval instar with $\mathrm{LC}_{50}$ values $\left(1.2 \mathrm{ppm}\right.$ for $4^{\text {th }}$ larval instar).

The maximum production and perception of pheromone on both sexes resulted from treated $4^{\text {th }}$ larval instar were at 8-10 days old while at 4-6 days old in untreated sexes.

The maximum and minimum pheromone production and perception by sexes resulted from treated $4^{\text {th }}$ larval instar were at $30^{\circ} \mathrm{C}$, while it decline to its lowest titer at $15^{\circ} \mathrm{C}$.

The study revealed that both sexes resulting from treated $4^{\text {th }}$ larval instar with $\mathrm{LC}_{50}$ of Chlorfluazuron caused the formation of abnormal antennae and effect on number and distribution of the sensillae.

Keywords: Tribolium castaneum, Chlorfluazuron, pheromone production and perception, Age, Temperature, scan antennae.

\section{INTRODUCTION}

The red flour beetle, Tribolium castaneum (Herbst) (Coleoptera: Tenebrionidae), is a common insect pest associated with food- processing facilities worldwide Mills and Pedersen (1990), so we must control this pest by safe means.

Nowadays, alternative methods are being appreciated. One of these methods may be the inclusion of insect growth regulators (IGRs) such as Chlorfluazuron . These compounds are highly effective against various insects attacking stored products and other pests that have become resistant to organic insecticides. Meanwhile, all these compounds are less toxic to mammals and non target organisms (Horowitz, 1998).

Chlorfluazuron is effective as chitin synthesis inhibitors (CSI) ingredient that used to eliminate Coptotermes acinaciformis in Australia because it disrupts chitin deposition during ecdysis (Peters and Fitzgerald (2003), also, Abd El-Mageed and Elgohary (2007) used Chlorfluazuron in pest management strategies as safety environmental compound for controlling the two corn borers Sesamia cretica Led. and Ostrinia nubilalis Hun.

Pheromones are a class of semiochemicals that insects and other animals release to communicate with other individuals of the same species Mueller (1995).

This study investigate the possibilities of using Chlorfluazuron and sex pheromone in control this destructive pest. 


\section{MATERIALS AND METHODS}

\section{Rearing insect and bioassay test:}

Red flour beetle, T. castaneum was reared for many generations under constant conditions $30{ }^{\circ} \mathrm{C}$ and $70 \%$ R.H. in the Department of Entomology, Benha University. The rearing medium was wheat flour mixed by weight with Brewer's yeast (95:5, w:w). Chlorfluazuron (Atabron) " $5 \%$ EC" was diluted in water at the concentrations of $0.1,0.5,1,5$ and $10 \mathrm{ppm}$, then transferred into suitable media. Four replicates $(25$ $4^{\text {th }}$ larval instar) were run for each concentration and a control with water was used for comparison in the diet. A preliminary experiment was carried out to determine the effect of $\mathrm{LC}_{50}$ of Chlorfluazuron as a chitin synthesis inhibitor against $4^{\text {th }}$ larval instar of T. castaneum.

Factors influencing sex pheromone production and perception:

\section{a- Effect of age on $T$. castaneum adult treated as $4^{\text {th }}$ larval instar on pheromone production and perception}

To investigate the effect of age on pheromone production and perception, hexane extracts were prepared from treated virgin females at 0.3 equivalents (FE) per $10 \mu$ of solvent of various ages ( $0-2,2-4,4-6,6-8,8-10,10-12$ and 12-14 days). Each treated female age group extract was tested in ten replicates each one contains 10 treated males (10-12 days old) placed individually in 10 vials. One hundred treated males of various ages (0-2, 2-4, 4-6, 6-8, 8-10 and 10-12 days old) were tested for single treated female extract (10-12 days old) as previous manner. Untreated males and females were used according to the previous manner for control.

\section{b- Effect of temperature on $T$. castaneum adult treated as $4^{\text {th }}$ larval instar on pheromone production and perception}

To find out the effect of temperature on extractable pheromone content. Treated virgin female pupae reared at $30^{\circ} \mathrm{C}$, until reach adult were incubated at different temperatures $\left(15,25,30\right.$ and $\left.40^{\circ} \mathrm{C}\right)$. Then treated adult females were removed and were extracted for pheromone production after 8-10 days from adult emergence at each temperature. The extracts were tested against treated males 8-10 days old reared at $30{ }^{\circ} \mathrm{C}$. For each extract, ten replicates each one contains 10 treated males placed individually in 10 vials were used. Untreated males and females were used according to the previous manner for control.

c- Scanning examination of antennal sensillae of adult T. castaneum.

The fine structure and distribution of various types of antennal sensilla at 8-10 days old female and male resulting from $4^{\text {th }}$ larval instar treated with $\mathrm{LC}_{50}$ of Chlorfluazuron was compared with those of untreated individuals by using scanning electron microscopy (SEM) with high vaccum mode at the Regional Center of Mycology and Biotechnology, Cairo, Egypt.

Statistical analysis

The results obtained were evaluated using one way analysis of variance "ANOVA" (Snedecor, 1971) on origin Pro. Lab (version 7.5) statistical program at one level of significance $(\mathrm{P}<0.01)$.

\section{RESULTS AND DISCUSSION}

The treated $4^{\text {th }}$ larval instar showed a high sensitivity to Chlorfluazuron where $\mathrm{LC}_{50}$ value was $1.2 \mathrm{ppm}$. These results similar to those obtained by Bakr et al. (2005) on Monomorium pharaonsis. These results may be due to Chlorfluazuron is a chitin 
synthesis inhibitor that belongs to benzoylphenyl- -ureas (BPUs) and acts as an antimolting agent, inhibit biosynthesis of chitin of an important constituent in insect cuticle larvae (Dhadialla et al., 2005).

We applied the $\mathrm{LC}_{50}$ of Chlorfluazuron under some factors to illustrate these sensitivity on both sexes.

\section{I)Effect of age on pheromone production by females at different ages:-}

Normal female produced maximum sex pheromone titer at 4- 6 days old. While female produced from treated $4^{\text {th }}$ larval instar with $\mathrm{LC}_{50}$ of Chlorfluazuron appeared to produce lesser amounts of a sex pheromone which significantly $(\mathrm{P}<0.01)$ increases gradually to reach a peak at 8-10 days old. On the other hand, production of pheromone in untreated virgin females extract were significantly higher than treated one at different ages from 0-14 days old. These data are represented graphically in Fig (1).

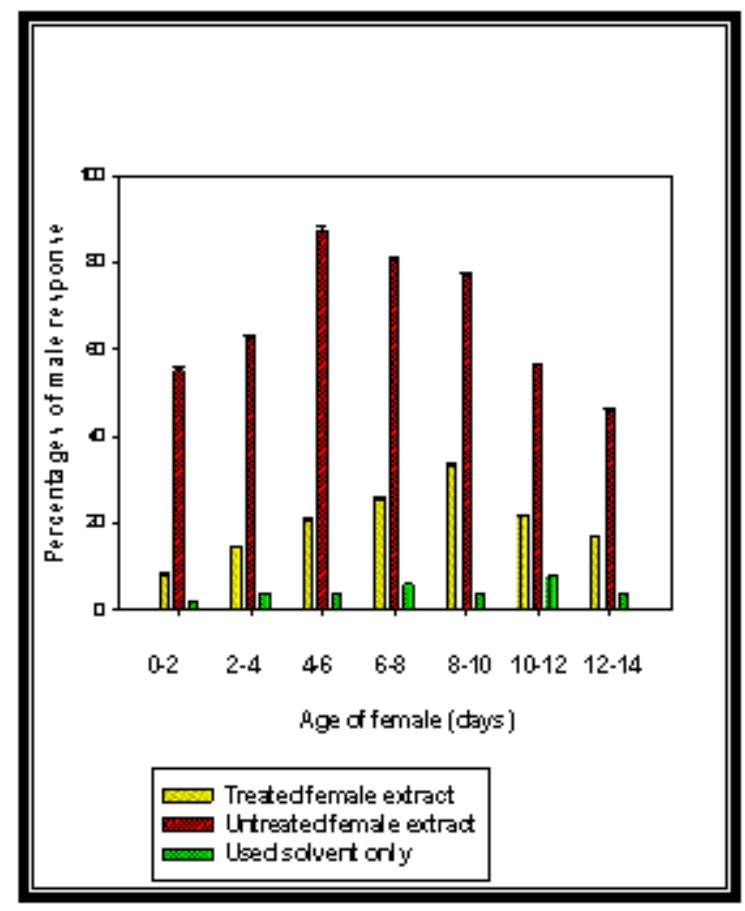

Fig. 1: Average male response of Tribolium castaneum to pheromone extracts of females at different ages produced by treated $4^{\text {th }}$ larval instar by Atabron.

These results agreed with Barratt (1974) who indicated that the maximum pheromone production by the normal female drug store beetle, Stegobium paniceum (L.), 3 to 4 days old. In contrast results obtained by Xiang et al. (2010) which reported that the percentage of sex pheromone production by female black cutworm moth, Agrotis ipsilon increased in 1 to 3days-old females and decreased in 3 to 7 days-old females. Females advanced their pheromone production time with increasing age.

\section{II) Effect of age on pheromone perception by males at different ages:-}

The data obtained on the response of males resulted from treated $4^{\text {th }}$ larval instars with $\mathrm{LC}_{50}$ of Chlorfluazuron at different ages to treated female extracts are represented graphically in Fig. (2).

The response of treated males started at a low level $06.12 \%$ for young males $0-2$ days old. It increased as the males became older 2-8 days old. The maximum response $31.25 \%$ was reached when treated males were 8-10 days old. 
Much older treated males showed variable levels of response, that were somewhat lower than that of 8-10 days old males. The level of male response dropped to $14.29 \%$ at the age of $12-14$ days old.

No significant difference between the maximum response of treated males 8-10 days old and the response of treated male 6-8 days old. A significant difference, was found among the maximum response of males 8-10 days old and the response of males (0-2, 2-4, 4-6, 10-12 and 12-14 days old).

These results indicated that the optimum age of treated male and treated female for perception and production sex pheromone was likely 8-10 days old.

Although responsiveness to pheromone in untreated virgin males was significantly higher than treated one at different ages from 0-14 days old. The maximum responsiveness to pheromone in untreated virgin males was at 4-6 days old. Similar result obtained by Spurgeon (2003) on boll weevil.

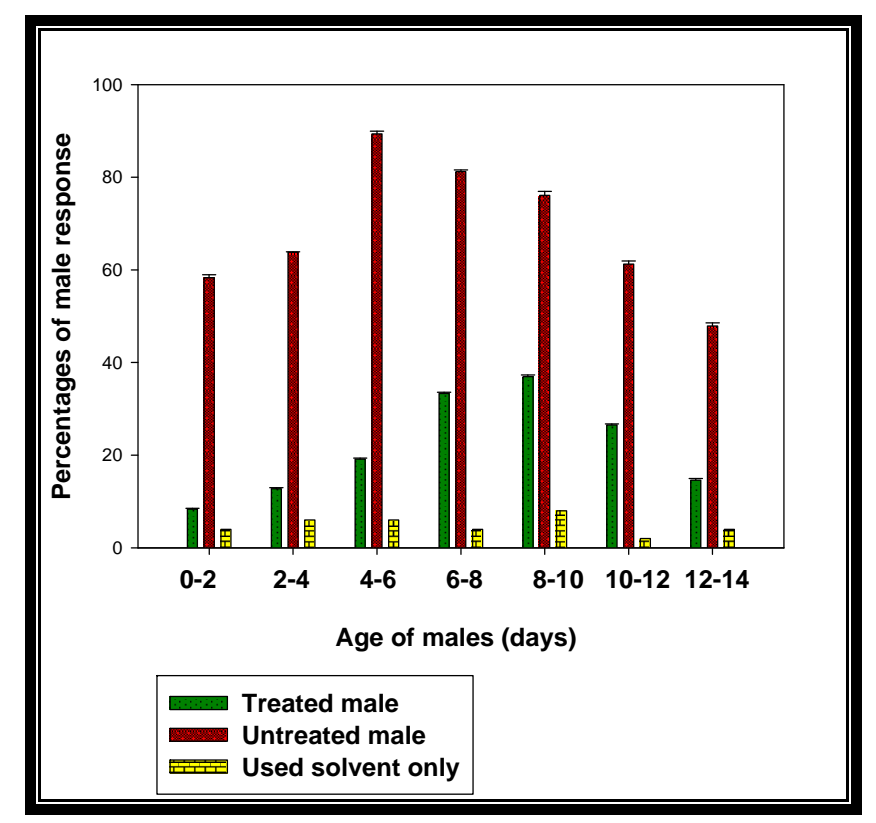

Fig. 2: Average male response of T. castaneum at different ages to female extracts produced by treated 4th larval instar by Atabron.

\section{III)Effect of Temperature:-}

Males resulting from treated $4^{\text {th }}$ larval instar were exposed to pheromone extracts of treated females reach lowest level at $15^{\circ} \mathrm{C}$ and the male response increased gradually to reach its maximum at $30^{\circ} \mathrm{C}$, but, the male response started to decrease at $40{ }^{\circ} \mathrm{C}$. The difference, however, was not significant from the response level at $30{ }^{\circ} \mathrm{C}$. These results represented graphically in Fig. (3). Although responsiveness and production of pheromone in untreated groups were significantly $(\mathrm{P}<0.01)$ higher than treated one at different rearing temperatures.

Results of the present study indicated that beetles of $T$. castaneum are active throughout a wide range of temperature and none of the tested temperatures could inhibit pheromone production. This indicates that temperatures favourable for its life are also favourable for sex pheromone production; and that higher temperatures are more favourable than lower one. These results similar to those obtained by Webster and Carde (1982) who showed that the decrease of the temperature of untreated females of the omnivorous leafroller moth, led to reduction in the pheromone titer inside the sex pheromone gland. 


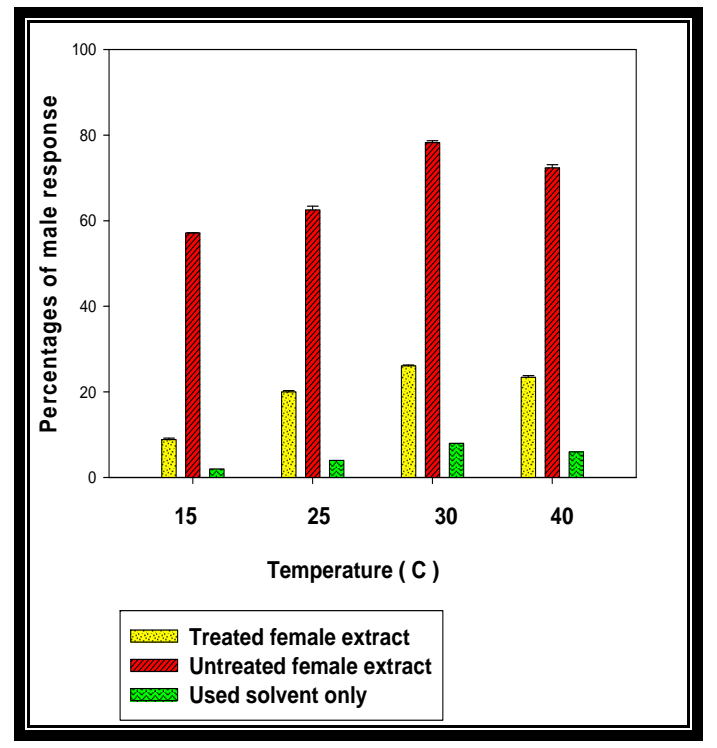

Fig. 3: Response of male Tribolium castaneum produced after treated $4^{\text {th }}$ larval instar with Atabron to sex pheromone extracts of females kept at different temperatures

\section{Effect of Chlorfluazuron on the Antennal Sensilla of adult Male T. castaneum :}

The long capitate antennae of these beetles consist of the scape, pedicel and eleven flagellomeres, even the last three segments at the tip of antennae are abruptly larger than the preceding one. Types of antennal sensillae in both males and females are different.

By using scan electron microscopy, seven types of normal male antennal sensillae were found in antennae: male antennae has (Trichodea type I " $\mathrm{T}_{1}$ ", Trichodea type II "T${ }_{2}$ ", Trichodea type III " $\mathrm{T}_{3}$ ", Chaetica sensillae "CH", Böhm sensillae "BS", Campaniform sensillae "CS", and Basiconica sensillae "B") as shown in plate (1-a) and the last segment contains all the previous types of sensillae except Campaniform sensillae as shown in plate (1-b). Similar results obtained by Merivee et al., 2000 on antennal sensillae of the male ground beetle Bembidion lampros, while male adult antennae resulted from treated $4^{\text {th }}$ larval instar with $\mathrm{LC}_{50}$ of Atabron revealed that, the antennae of treated group lost their normal shape. The number of male antennal segment decreased with weak and fragile sensillae at dorsal side as shown in Plate (1-c) and the last three segments confused and without sensillae as shown in Plate (1-d).

Effect of Chlorfluazuron on the Antennal Sensilla of adult Female T. castaneum:

Normal female antenna with three types only of sensillae (Trichodea type I " $\mathrm{T}_{1}$ ", Trichodea type II " $\mathrm{T}_{2}$ " and Trichodea type III " $\mathrm{T}_{3}$ "), as shown in plate (2-a) and the last segment has the three previous types of sensillae, as shown in plate (2-b), Similar results obtained by Merivee et al. (2001) on antennal sensillae of the ground beetle Platynus dorsalis.

The previous results illustrated that antennae of male have more types of sensillae than female, so, it may contain the receptor sites for the female sex pheromone, that agreed with Timothy (2005) who reported that an increased number of sensillae, through lengthening, branching or thickening of antennal segments would increased sensitivity.

On the other hand female adult antennae resulted from treated $4^{\text {th }}$ larval instar with $\mathrm{LC}_{50}$ of Atabron showed antennae with highly confused segments without sensillae as shown in Plate (2-b) and the last three segments confused but without 
sensillae as shown in Plate (2-d). Similarily, obtained by Zohry (2008) who revealed that $\mathrm{LC}_{50}$ of flufenoxuron on $3^{\text {rd }}$ larval instar of Spodoptera littoralis caused the formation of abnormal antennae and affect the length and distribution of sensillae.

\section{REFERENCES}

Abd El-Mageed, A.E.M. and Elgohary, L.R.A. (2007). Possibility of replacing the conventional insecticides with safty environmental compounds for controlling the two corn borers Sesamia cretica Led. and Ostrinia nubilalis Hun. Journal of Entomology. 4(6): 451- 456.

Bakr, R.F.A.; Hafez, G.A.; Ibrahim, A.I. and Abdou, M.A. (2005). Toxicological effects of pyriproxyfen and chlorfluazuron (IGRs) on Monomorium pharaonsis (Hymenoptera :Formicidae) in laboratory and field, African J. Biol. Sci., 1(1): 49- 58.

Barratt, B.I.P. (1974). Timing of production of a sex pheromone by females of Stegobium paniceum (L.) (Coleoptera: Anobiidae) and factors affecting male response. Bull. Ent. Res., 64: 621- 628.

Dhadialla, T.S.; Retnakaran, A. and Smagghe, G. (2005). Insect growth and development disrupting insecticides. In: Gilbert, L.I.; Kostas, I. and Gill, S. (Eds.). Comprehensive Insect Molecular Science. Vol. 6. Pergamon Press, New York, NY. pp. 55- 116.

Merivee, E.; Ploomi, A.; Luik, A.; Rahi, M. and Sammelselg, V. (2001). Antennal sensilla of the ground beetle Platynus dorsalis (Pontoppidan, 1763) (Coleoptera, Carabidae). Microsc. Res. Tech., 55:339- 349.

Merivee, E.; Ploomi, A.; Rahi, M.; Luik, A. and Sammelselg, V. (2000). Antennal sensilla of the ground beetle Bembidion lampros Hbst (Coleoptera, Carabidae). Acta Zoologica, 81: 339- 350.

Mills, R. and Pedersen, J. (1990). A ßour mill sanitation manual. Eagan Press, St. Paul, MN.

Mueller, D.K. (1995). Pheromones. Chapter 25 in Moreland, D. (ed.) Handbook of Pest Control, 8th edition. Mallis Handbook and Technical Training Company. $1454 \mathrm{pp}$.

Peters, B.C. and Fitzgerald, C.J. (2003). Field evaluation of the bait toxicant chlorfluazuron in eliminating Coptotermes acinaciformis (Froggatt) (Isoptera: Rhinotermitidae). J. Econ. Entomol., 96: 1828- 1831.

Snedecor, G. W. (1971). Statistical methods, $14^{\text {th }}$. Ed. The Iowa College Press, Am., U.S.A.

Spurgeon, D.W. (2003). Age dependence of pheromone production by the boll weevil (Coleoptera: Curculionidae). Environ. Entomol., 32(1):31- 38.

Timothy, C. (2005). External morphology of antennal sensilla in relation to the host searching behavior of Liporrhopalum tentacularis Grandi (Hymenoptera: Agaonidae). BLGY 3040 Project Report.

Webster, R.P. and Carde, R.T. (1982). Relationships among pheromone titre, calling and age in the omnivorous leafroller moth, Platynota stultana. J. Insect Physiol., 28: 925- 933.

Xiang, Y.Y.; Yang, M.f. and Li, Z.Z. (2010). Calling behavior and rhythms of sex pheromone production in the black cutworm moth in China. J. Insect Behavior, 23(1): 20-31.

Zohry, N.M.H. (2008). Effect of flufenoxuron on the antennal sensilla of Spodoptera littoralis (Lepidoptera: Noctuidae). Egypt. Acad. J. Biol. Sci., 1(2):13- 25. 
Plate1: Scanning electron microscopy of antennal sensillae of male T. castaneum.

Normal Male

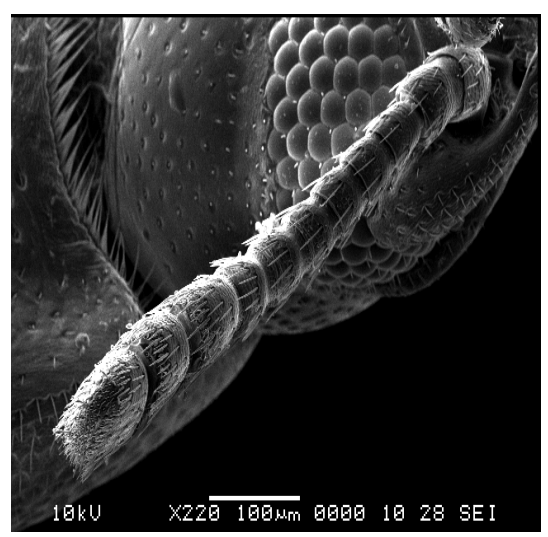

a) General View of antennal segment of normal male

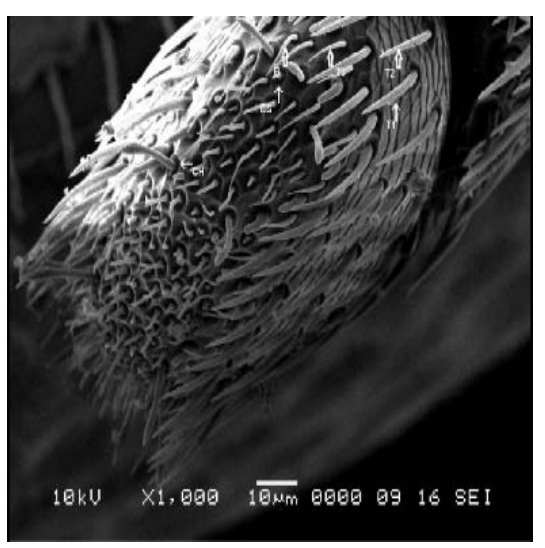

c) Last segment (No. 11)
Treated Male

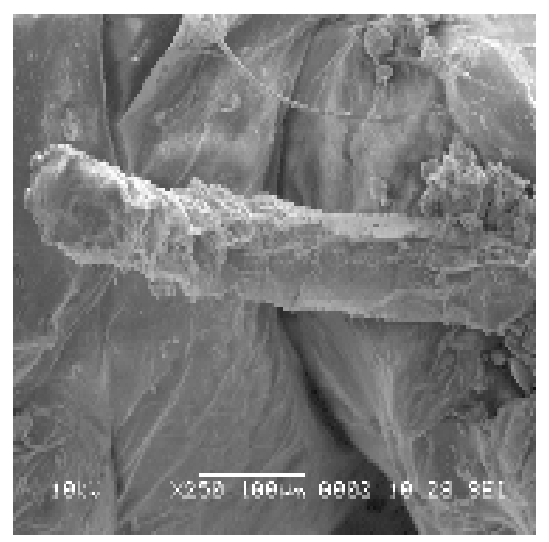

b) General View of antennal segment of treated male

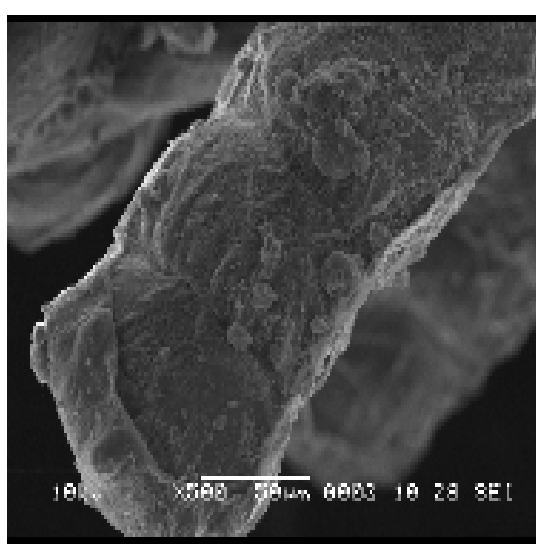

d) Last 3 segments (No. 9, 10 \&11)Plate 2: 
Plate2: Scanning electron microscopy of antennal sensillae of female T. castaneum.

Normal Female

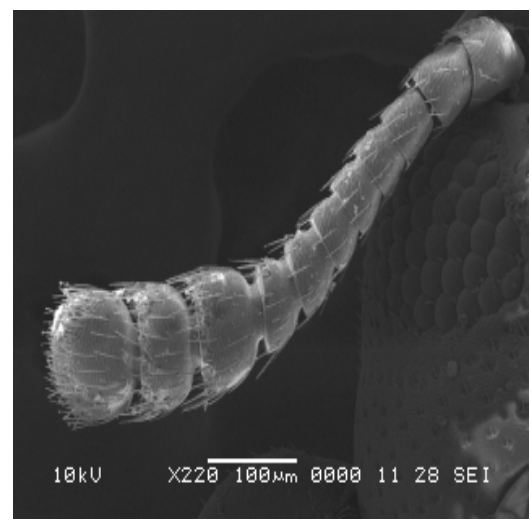

a) General view of antennal segment of normal female.

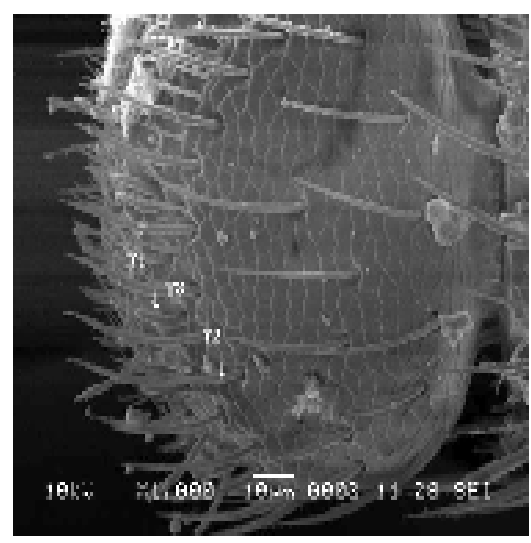

c) Segment number 11 of female antenna showing three types of trichodea $(\mathrm{T} 1, \mathrm{~T} 2 \& \mathrm{~T} 3)$
Treated Female

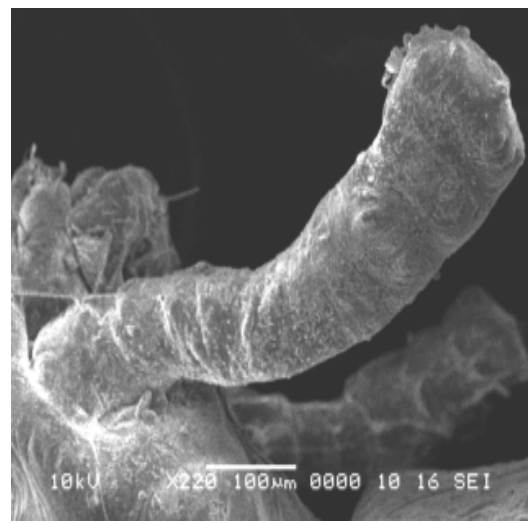

b) General View of abnormal antennal segments.

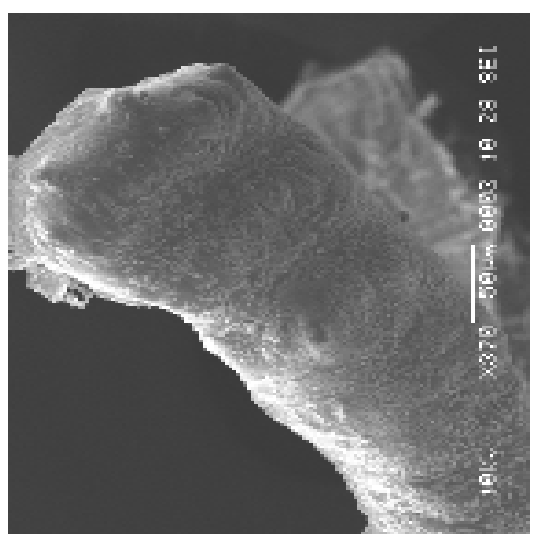

d) Last segments of female antennae showing absence of sensillae with destroyed tissue. 


\section{ARABIC SUMMARY}

بعض العوامل المؤثرة فى إنتاج وادراك الفيرمون والتركيب الاقيق لقرون الاستشعار لحشرة خنفساء الدقيق الناتجة من المعاملة بالكلورفليوزورئ الترون الآن

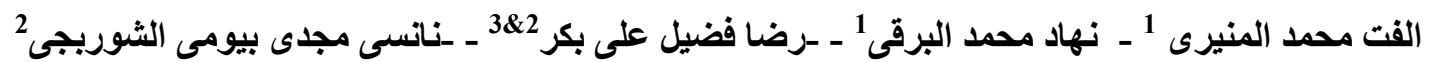

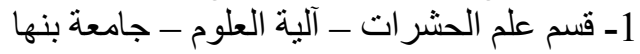

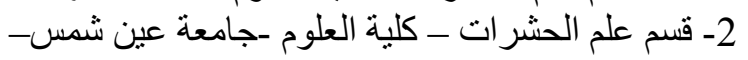

3-قسم الاحياء - كلية العلوم - جامعة الملك خالد- ابها - المملكة العربية السعودية

الكلورفليوزورون هو منظم نمو حشري والذى ينتمى لمجموعة بينزويل فينيل يوريا و يستخدم لمكافحة

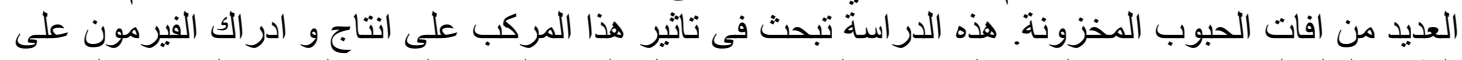

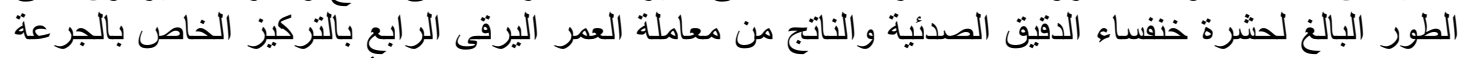

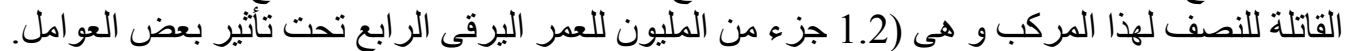

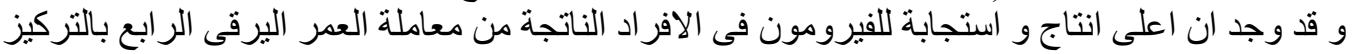

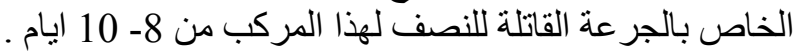

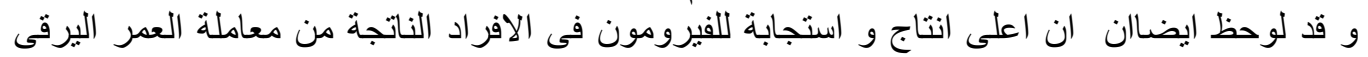

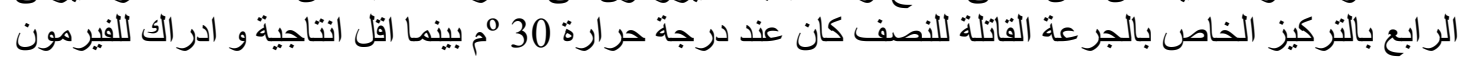

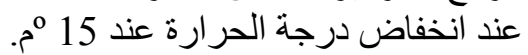
و بفحص قرون الاستشعار للحشرة وجد اند ان الذكور لديهم 7 انواع من الثعبرات الحسية على قرون

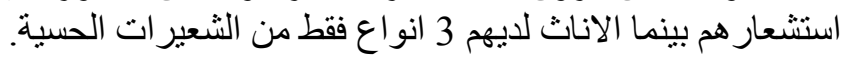

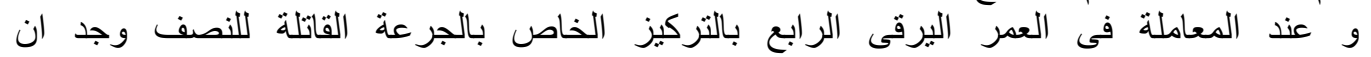

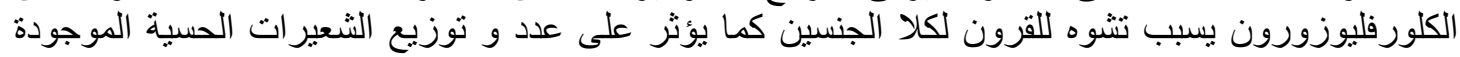

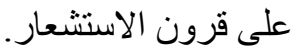

